\title{
Conceptual Models Development of Non-Formal Education Unit Management for Education Services Quality
}

\author{
${ }^{1}$ ASEP SAEPUDIN, ${ }^{2}$ ADE SADIKIN AKHYADI, ${ }^{3}$ IIP SARIPAH \\ 1,2,3 Universitas Pendidikan Indonesia, Dr. Setiabudhi No. 229 Street, Bandung, Indonesia, \\ email: ${ }^{1}$ aspudin@gmail.com; ${ }^{2}$ ades.akhyadi@gmail.com; ${ }^{3}$ iipsaripah@ymail.com
}

\begin{abstract}
Non-formal education units broadly known by the public are the Community Learning Center (CLC) and Courses and Training Institution (CTI) which have so far been able to improve the quality of education for the community. This study focuses on the description of the capacity mapping management of non-formal education units in improving the quality of education services. The research method used is a qualitative approach with descriptive methods. The research subjects are managers, educators, and students in non-formal education units in Bandung. Data collection techniques used are documentation study, interviews, and focused discussion. This research results in several points, that: (1) description of management of CLC and CTI in Bandung is still not optimal, (2) the map of the quality standards of CLC and CTI in Bandung have not reached the eight National Education Standars yet, (3) expectations of CLC and CTI management are collected and formulated as a conceptual model for the performance of CLC and CTI managers in Bandung.
\end{abstract}

Keywords: capacity of management, non-formal education, quality of service.

\section{Introduction}

The development of science and technology related to the needs of the community requires the availability of quality and diverse educational services. For this reason, education is very strategic in developing capabilities and forming the dignified character and civilization of the nation in the context of the intellectual life of the nation (UUSPN No. 20 in 2003). To put this goal into reality requires quality education as suggested by Amin (2014: 2) that each education unit should analyze the model and quality of education. Quality education is closely related to the capacity of implementing and managing education that fulfills the criteria for managing education based on applicable education quality standards. In relation to the availability of quality and diverse educational units, non-formal education units occupy a strategic position.

Non-formal education unit is a popular term since the early 1990s. Ardiwinata (2014: 100 ) explained that in the World Declaration on
Education For All (EFA), in Jomtien, Thailand, participants of the declaration initiated the Community Learning Center (CLC) which later became known as CLC. Sihombing and Gutama (2000: 34) realize that CLC and CTI are education units developed and managed by the community outside the formal education system. Philosophically, CLC and CTI have a social function such as a driver, a guide, and a bastion of protection (Abdulah and Putra, 2018: 4). Theoretically, Saepudin, (2015: 95) defines CLC as a non-formal education unit whose activities are independently carried out in an organized and systematic way outside the established schooling system or is an important part of other broader activities, intentionally conducted to serve certain students in achieving their learning goals.

Conceptually, education services at CLC and CTI education units apply the concept of a modern learning revolution where achievements are reached through learning. Hayati (2011: 181) in her research concludes that achievement will never be produced as long as someone has never carried out

Received: 2019-08-30, Revised: 2019-10-28, Accepted: 2019-12-23

Print ISSN: 0215-8175; Online ISSN: 2303-2499. DOI: https://doi.org/10.29313/mimbar.v35i2.5055

Accredited Sinta 2 based on the decree No.10/E/KPT/2019 until 2024. Indexed by DOAJ, Sinta, Garuda, Crossreff, Dimensions 
learning activities. For this reason, learning as an affiliate of education has a strategic position as Helmut (1991: 57) states that education is a catalyst in the process of social transformation in encouraging the differentiation of one's way of life.

Based on the thought above, the application of learning programs at CLC and CTI should be a comprehensive educational approach for citizens outside formal education. Related to the characteristics and trends of non-formal education problems currently leading to the handling of real community needs, the orientation of CLC and CTI programs as non-formal education units is projected on community education with the Community Based Education (CBE) approach.

According to Jalal and Supriadi (2001: 31), Community Based Education (CBE) emphasizes the importance of community understanding, characteristics, needs, weaknesses, and strengths they have. In its implementation, CBE is a method that emphasizes competency through solving problems in the community by utilizing the potential of the environment (to help people to help themselves). This is related to the objectives of organizing non-formal education programs that is to improve competence. According to Anwas (2011: 193), competence is an ability based on knowledge, skills, and supported by the attitude required in carrying out work. One of the means to increase competence relevant to the needs of the community is through learning at CLC and CTI education units. For this reason, CLC is an alternative education for optimizing the quality of society, as revealed by Hermawan and Suryono (2016: 2) that community development through CLC must optimize the active role of the community itself. A development that involves the community as actors will certainly provide many benefits. In his study, Widodo (2019: 31) stated that the dynamics of development caused the welfare responsibility distribution scheme to change, from a single-actor to a multiactor. The state is no longer the sole actor to solve development problems. Therefore, CLC managers who born and grow in the community are potential development actors and it is evident that community development through CLC has improved community life skills as Septrilia, Husin, Hakim (2019: 3) grouped them into five categories: selfawareness, social skills, thinking skills, academic skills, and vocational skills.
Based on empirical data, CLC and CTI in Bandung have been proven to be able to improve life skills of the community as quality human resources. Saepudin (2017: 254) states that learners of CLC are able to show their growing sense of confidence in their ability to achieve success. However, on average, CLC and CTI in Bandung have not optimally adjusted the education quality standards to the National Education Standard indicators. This is because not all CLC and CTI have the feasibility seen from the management aspects of implementation, standardization, and administrative order, as well as the physical feasibility of the institution as the provider of education. Of course, to achieve the optimization of the quality of education services, it is necessary to optimize the performance of education unit managers. In relation to optimizing the quality of education services, Suharto (2005: 3 ) explains that there are three aspects in optimizing education: the regulation focuses on structuring quality curriculum, professionalism focuses on the rights and authority of educators, and management emphasizes on the policies and controls of managing education units.

Based on the description above, efforts to develop the quality of education services and manager's performance in organizing education through non-formal education require government intervention including universities by intensive and sustainable assistance. Therefore, it is reasonable if CLC and CTI as non-formal education units get more attention and be strengthened as educational institutions that have been proven capable of empowering the community through various educational programs according to the needs of the community. Sihombing (2019) states that the purpose of institutionalizing non-formal education is to explore, to grow, to develop, and to utilize all the potential exists in the community. For this reason, the existence of CLC and CTI, in turn, will enhance community empowerment. Iskandar (2017: 50) explains that community empowerment is an effort to improve the welfare of the community through various activities to increase community initiatives and self-help, environmental change, development of community economic ventures, and various activities that can increase community production output. In other words, Firdausi (2016: 42) explains that community empowerment is defined as an effort to transform potential human resources 
into actual ones.

Based on the above thought, this research is determined to strengthen CLC and CTI institutions in Bandung. The expected benefit of this research is that it can empirically reveal the condition of non-formal education unit institutions (CLC and $\mathrm{CTI}$ ), the quality management of the implementation of educational programs, and the conceptual design of manager's performance development at non-formal education units (CLC and CTI) in Bandung.

\section{Research Methodology}

This study uses a qualitative approach with descriptive method because this study reveals the current empirical phenomenon (Sugiyono, 2012: 3). The research subjects as the main data source are the elements of CLC and CTI, managers, and tutors in Bandung. This research is conducted in the areas of Bandung City, Bandung Regency, West Bandung Regency, and Cimahi City. Each area is represented by two institutions: CLC and CTI. Research subjects or informants are determined by purpose sampling techniques. The number of research subjects was 16 people, 4 CLC managers, 4 CLC tutors, 4 CTI managers, and 4 CTI instructors.

The research variables explored from the research subjects are 1 ) description of the management of CLC and CTI institutions in Bandung, 2) map of the quality standards of CLC and CTI units in Bandung, and 3) description of the conceptual model of manager's performance development at CLC and CTI institutions in Bandung. Data collection techniques used are observation, interviews, documentation, and questionnaires. Data analysis techniques are carried out through the following steps (1) data reduction, (2) data display, and (3) conclusion or verification. Arikunto (2010: 25$)$ states that in research activities, researchers must at least prepare the preparation and reporting steps of preparation. This research conducts four steps: (a) the preparatory step (pre-field), (b) the fieldwork step (data collection), (c) the data analysis step, (d) the reporting step.

\section{Results And Discussion \\ Management of CLC and CTI Institutions in Bandung}

The study of institutions management on each research subject is the performance of institutions in preparing plans, organizing, mobilizing, guiding, assessing and developing institutions to get better.

The conditions of management of CLC and CTI institutions can be described based on aspects of planning, organizing, mobilizing, guiding, assessing and, developing as follows:

First, planning for each CLC is generally carried out relating to the sub-aspects of identifying needs, formulating goals, drafting curriculum, recruiting educators, preparing activity schedules, and providing facilities. Second, organizing the CLC and CTI programs generally takes the form of organizational structure, task description, selection, and placement of personnel. Third, the mobilization of each CLC and CTI is relatively different from one another. It is observed in the aspect of mobilization regarding the preparation of motivational guidelines, forms of motivation, steps of motivation, and impact of motivation. Fourth, guiding the CLC and CTI supervision and monitoring activities. Supervision activities in CLC and CTI institutions generally are the implementation of routine supervision and monitoring by supervisors from the local Education Office. Fifth, assessment of CLC and CTI institutions is an evaluation related to aspects of preparation instrument, assessment approaches, and assessment steps. Sixth, the development of CLC and CTI programs is activities aimed at future improvement, including development steps, continuing programs, and the development of cooperation networks.

Based on the description above, it can be concluded that the management of non-formal education unit institutions in Bandung has generally carried out planning and organizing activities. However, organizing activities carried out is relatively varied and guiding has not been carried out optimally, especially on internal control activities. Furthermore, the process of evaluating and developing institutions has not yet evenly conducted in each of the non-formal education units.

\section{Map of Indicators of Quality Standards of CLC and CTI Units in Bandung}

Map of indicators of the quality standards of CLC and CTI units is analyzed based on the National Education Standards which consist of eight standard indicators (BSNP, 
2005) that is : (1) graduate competency standard indicators, (2) content standard indicators, (3) process standard indicators, (4) educator staff standard indicators, (5) education personnel standard indicators, (6) management standard indicators, (7) funding standard indicators, and (8) assessment standard indicators. The following describes the results of the quality distribution of 4 CLC units and 4 CTI units in Bandung which covered the area of Bandung City, Bandung Regency, West Bandung Regency and Cimahi City based on National Education Standards indicators.

\section{CLC and CTI Quality Standards in Bandung City}

Research samples in Bandung City are Sukamulya CLC and Ratna Ayu CTI. Sukamulya CLC is located at Cirengot street No. 16 Rt. 04, Rw. 04 Sukamulya, Cinambo District, Bandung City. Based on the eight National Education Standards, the results of mapping the quality standard indicators of CLC Sukamulya are shown in table 1.

Based on data in table 1, Sukamulya CLC seen from the graduate competency standards has fulfilled the ideal criteria with the total number fulfilled. It shows the number of standard indicators fulfilled 2 with a percentage of $100 \%$, which means it is very adequate. Based on the content standard, it has not fully fulfilled the number of standard indicators. The number of standard indicators is 5 of 8 with a percentage of $62.5 \%$, which means it is adequate. Based on the standard process, the number of standard indicators is equal to the number of indicators fulfilled 7 with a percentage of $100 \%$, which means it is very adequate. Based on the standards of educators and education personal, the number of standards is 4 of 6 with a percentage of $66.6 \%$, which means it is adequate. Based on the standard of facilities and infrastructure, the number of standards fulfilled is the same as the number of standard indicators which is 6 with a percentage of $100 \%$, which means it is very adequate. Based on management standards, the number of standards is 23 of 28 with a percentage of $82.14 \%$, which means it is very adequate. Based on the financing standard, the number of standards is equal to the number of ideal standard indicators 5 with a percentage of $100 \%$, which means it is very adequate. While based on the assessment standard, the number of standards is 6 of 10 with a percentage of $60 \%$, which means it is adequate. Thus, based on the eight aspects above, it can be concluded that Sukamulya CLC is assessed very adequate because the final percentage shows $80.5 \%$ with a standardized number 58 of 72 total indicators.

The results of the mapping of eight National Education Standards of Ratna Ayu CTI located at Ciateul Tengah street No. 15 RT. 07 RW. 06 Pungkur, Regol District, Bandung City are shown in table 2.

Based on the results of data in table 2, the status of Ratna Ayu CTI achievement is very adequate with a percentage of $80.5 \%$. This is due to its success in fulfilling each standard. From the competency standard graduates, this CTI obtained $66.7 \%$ with the number of indicators fulfilled 2 and not fulfilled 1 ( 3 indicators that must be fulfilled). From the content standard, this CTI obtained $81.8 \%$ with an average number of indicators fulfilled 9 and not fulfilled 2 (11 indicators that must be fulfilled). From the standard process, it obtained $64.2 \%$ with a number of indicators 9 and not fulfilled 5 (14 indicators that must be fulfilled). From the standard of educators and education staff, it obtained $33.3 \%$ with the number of indicators fulfilled 2 and not fulfilled 4 (6 indicators that must be fulfilled). From facilities and infrastructure standards, it obtained $81.8 \%$ with the number of indicators fulfilled 9 and not fulfilled 2 (11 indicators that must be fulfilled). From management standard, it obtained $94.7 \%$ with a total of indicators fulfilled 8 and not

Table 1

Mapping Data at Sukamulya CLC

\begin{tabular}{|c|c|c|c|c|c|c|c|c|c|}
\hline \multirow[t]{2}{*}{ Achievement Targets } & \multicolumn{8}{|c|}{ Standard } & \multirow[t]{2}{*}{ Total Description } \\
\hline & 1 & 2 & 3 & 4 & 5 & 6 & 7 & 8 & \\
\hline Fulfilled & 2 & 5 & 7 & 4 & 6 & 23 & 5 & 6 & 58 \\
\hline Standard indicator & 2 & 8 & 7 & 6 & 6 & 28 & 5 & 10 & 72 \\
\hline Not fulfilled & 0 & -3 & 0 & -2 & 0 & -5 & 0 & -4 & -14 \\
\hline Percentage (\%) & 100 & 62.5 & 100 & 66.6 & 100 & 82.14 & 100 & 60 & 80.5 \\
\hline
\end{tabular}

Source: Data Analysis Result (2018). 
Table 2

Mapping Data of Ratna Ayu CTI

\begin{tabular}{|c|c|c|c|c|c|c|c|c|c|c|}
\hline \multicolumn{9}{|c|}{ Ach i e ve ment Standard } & \multirow{2}{*}{\multicolumn{2}{|c|}{ Total Description }} \\
\hline Targets & 1 & 2 & 3 & 4 & 5 & 6 & 7 & 8 & & \\
\hline Fulfilled & 2 & 9 & 9 & 2 & 9 & 18 & 5 & 8 & 62 & \\
\hline Standard indicator & 3 & 11 & 14 & 6 & 11 & 19 & 5 & 8 & 77 & \\
\hline Not fulfilled & -1 & -2 & -5 & -4 & -2 & -1 & 0 & 0 & -15 & \\
\hline Percentage (\%) & 66.7 & 81.8 & 64.2 & 33.3 & 81.8 & 94.7 & 100 & 100 & 80.5 & \\
\hline
\end{tabular}

Source: Data Analysis Result (2018)

Table 3

Mapping Data of Queen Collage CLC

\begin{tabular}{|c|c|c|c|c|c|c|c|c|c|}
\hline \multicolumn{9}{|c|}{ Ach i e ve me nt Standard } & \multirow[t]{2}{*}{ Total Description } \\
\hline Targets & 1 & 2 & 3 & 4 & 5 & 6 & 7 & 8 & \\
\hline Fulfilled & 2 & 7 & 7 & 6 & 6 & 27 & 5 & 10 & 70 \\
\hline Standard indicator & 2 & 8 & 7 & 6 & 6 & 28 & 5 & 10 & 72 \\
\hline Not fulfilled & 0 & -1 & 0 & 0 & 0 & -1 & 0 & 0 & -2 \\
\hline Percentage (\%) & 100 & 87.5 & 100 & 100 & 100 & 96.4 & 100 & 100 & 97.2 \\
\hline
\end{tabular}

Source: Data Analysis Result (2018)

Table 4

Mapping Data of DPW Bandung Regency CTI

\begin{tabular}{|c|c|c|c|c|c|c|c|c|c|c|}
\hline \multicolumn{9}{|c|}{ Ach i e ve me nt Standard } & \multirow{2}{*}{\multicolumn{2}{|c|}{ Total Description }} \\
\hline Targets & 1 & 2 & 3 & 4 & 5 & 6 & 7 & 8 & & \\
\hline Fulfilled & 3 & 9 & 11 & 6 & 8 & 18 & 5 & 8 & 68 & \\
\hline Standard indicator & 3 & 11 & 14 & 6 & 11 & 19 & 5 & 8 & 77 & \\
\hline Not fulfilled & 0 & -2 & -3 & 0 & -3 & -1 & 0 & 0 & -9 & \\
\hline Percentage (\%) & 100 & 81 & 78 & 100 & 72 & 94 & 100 & 100 & 88.3 & \\
\hline
\end{tabular}

Source: Data Analysis Result (2018)

fulfilled 1 (19 indicators that must be fulfilled). From the financing standard, it obtained $100 \%$ with the number of indicators 5 , which means it has fulfilled the five indicators that must be fulfilled. Last, from the assessment standard, it obtained $100 \%$ with the number of indicators fulfilled 8 , which means that it has fulfilled the eight indicators that must be fulfilled.

\section{CLC and CTI Quality Standards in Bandung Regency}

Samples in Bandung Regency are Queen College CLC and DPW Bandung Regency CTI. CLC Queen College is located at Kopo Canal street No. 385/299 RT / RW 04/06 Margahayu District, Bandung Regency. Based on the eight National Education Standards, the results of the mapping of quality standard indicators of the Queen Collage CLC are obtained as in table 3.

Based on the results of data in table
3, Queen Collage CLC achievement status is very adequate with a percentage of $97.2 \%$. This is due to the success of Queen Collage CLC in fulfilling each of its standards. From the graduate competency standard, it obtained $100 \%$ with a number of indicators fulfilled 2, which means this CLC has fulfilled the two indicators that must be fulfilled. From the content standard, it obtained $87.5 \%$ with a total of 7 and not fulfilled 1 ( 8 indicators that must be fulfilled). From the standard process, it obtained $100 \%$ with a total of 7 indicators, which means that the CLC has fulfilled the seven indicators that must be fulfilled ( 7 indicators that must be fulfilled). From standards of educators and education staff, this CLC obtained $100 \%$ with a number of indicators 6 , which means that this CLC has met 6 indicators that must be fulfilled. From the standard of facilities and infrastructure, it obtained $100 \%$ with the number of indicators 6 , which means that it has fulfilled 6 indicators that must be fulfilled. From the management standard, this CLC obtained $96.42 \%$ with 27 
indicators and not fulfilled 1 (28 indicators that had to be fulfilled). From the financing standard, this CLC obtained $100 \%$ with the number of indicators 5 , which means that this CLC has fulfilled five indicators that must be fulfilled. Last, from the assessment standard, this CLC also obtained $100 \%$ with a number of indicators fulfilled 10, which means that this CLC has fulfilled 10 indicators that must be fulfilled.

The results of mapping the eight National Education Standards in DPW Bandung Regency CTI which is located at Jalan Raya Soreang Belakang No. 170 Ciloa RT 1 RW 1 Karamat Mulya, Soreang District, Bandung Regency, are shown in table 4.

Based on the results of data in table 4, DWP Bandung Regency CTI achievement status is very adequate with a percentage of $88.3 \%$. This is due to the success of this CTI in fulfilling each of its standards. From the graduate competency standard, this CTI obtained $100 \%$ with a number of indicators fulfilled 3, which means this CTI has fulfilled 3 indicators that must be fulfilled. From the content standard, this CTI obtained $81 \%$ with a total of indicator fulfilled 9 and not fulfilled 2 (11 indicators that had to be fulfilled). From the standard process, the CTI obtained $78 \%$ with the number of indicators fulfilled 11 and not fulfilled 3 (14 indicators that had to be fulfilled). From the standards of educators and education personnel, this CTI obtained $100 \%$ with a number of indicators 6 , which means that this CTI has fulfilled 6 indicators that had to be fulfilled. From the standard of facilities and infrastructure, this CTI obtained $72 \%$ with a number of indicators fulfilled 8 and not fulfilled 3 (11 indicators that must be fulfilled). From the management standard, it obtained $94 \%$ with a number of indicators fulfilled 18 and not fulfilled 1 (19 indicators that must be fulfilled). From the financing standard, this CTI obtained $100 \%$ with the number of indicators 5, which means that this CTI has fulfilled 5 indicators that must be fulfilled. Last, from the assessment standard, this CTI obtained $100 \%$ with a number of indicators fulfilled 8 , which means that this CTI has fulfilled 8 indicators that must be fulfilled.

\section{CLC and CTI Quality Standards in West Bandung Regency}

Samples in West Bandung Regency are Ash-Shoddiq CLC and An-Nur Harapan Ibu CTI, West Bandung Regency. Ash-Shoddiq
CLC is located at RT 02/RW 10 Pagerwangi, Lembang District, West Bandung Regency. Based on eight National Education Standards, the results of the mapping of quality standard indicators for the Ash-Shoddiq CLC are as in table 5 .

Based on the results of data in table 5, the Ash-Shoddiq CLC achievement status is adequate with a percentage of $69.4 \%$. This is due to its success in fulfilling each of its standards. From the graduate competency standard, this CLC obtained $100 \%$ with a number of indicators fulfilled 2, which means that this CLC has fulfilled the 2 indicators that must be fulfilled. From the content standard, this CLC obtained $50 \%$ with a total of indicator fulfilled 4 and not fulfilled 4 ( 8 indicators that must be fulfilled). From the standard process, this CLC obtained $85.7 \%$ with a total indicator fulfilled 4 and not fulfilled 1 ( 7 indicators that must be fulfilled). From the standards of educators and education personnel, this CLC obtained $33.3 \%$ with a number of indicators fulfilled 2 and not fulfilled 4 (6 indicators that had to be fulfilled). From the standard of facilities and infrastructure, this CLC obtained $83.3 \%$ with a number of indicators fulfilled 5 and not fulfilled 1 ( 6 indicators that must be fulfilled). From the management standard, this CLC obtained $78.6 \%$ with the number of indicators fulfilled 22 and not fulfilled 6 (28 indicators that must be fulfilled). From the financing standard, this CLC obtained $60 \%$ with a number of indicators fulfilled 3 and not fulfilled 2 ( 5 indicators that must be fulfilled). Last, from the assessment standard, this CLC obtained $60 \%$ with the number of indicators fulfilled 6 and not fulfilled 4 (10 indicators that must be fulfilled).

The results of mapping the eight National Education Standards indicators at An-Nur Harapan Ibu CTI, West Bandung Regency located at Cipanjak street No. 2, Cigugur Girang, Parongpong, West Bandung, are shown in table 6.

Based on the results of data in table 6 , the status of achievement of An-Nur Harapan Ibu CTI is very adequate with a percentage of $75.3 \%$. This is due to its success in fulfilling each of its standards. From the CTI graduates competency standards, this CTI gets $100 \%$ with the number of indicators fulfilled 3 , which means that this CTI has fulfilled 3 indicators that must be fulfilled. From the content standard, this CTI obtained $54 \%$ with the number of indicators fulfilled 6 and not 
Table 5

Mapping Data of Ash-Shoddiq CLC

\begin{tabular}{|c|c|c|c|c|c|c|c|c|c|}
\hline \multirow{2}{*}{$\begin{array}{l}\text { Achievement } \\
\text { Targets }\end{array}$} & \multicolumn{8}{|c|}{ Standard } & \multirow[t]{2}{*}{ Total Description } \\
\hline & 1 & 2 & 3 & 4 & 5 & 6 & 7 & 8 & \\
\hline Fulfilled & 2 & 4 & 6 & 2 & 5 & 22 & 3 & 6 & 50 \\
\hline Standard indicator & 2 & 8 & 7 & 6 & 6 & 28 & 5 & 10 & 72 \\
\hline Not fulfilled & 0 & -4 & -1 & -4 & -1 & -6 & -2 & -4 & -22 \\
\hline Percentage (\%) & 100 & 50 & 85.7 & 33.3 & 83.3 & 78.6 & 60 & 60 & 69.4 \\
\hline
\end{tabular}

Source: Data Analysis Result (2018)

Table 6

Mapping Data of An-Nur Harapan Ibu CTI

\begin{tabular}{|c|c|c|c|c|c|c|c|c|c|}
\hline \multicolumn{9}{|c|}{ Ach i e ve me nt Standard } & \multirow[t]{2}{*}{ Total Description } \\
\hline Targets & 1 & 2 & 3 & 4 & 5 & 6 & 7 & 8 & \\
\hline Fulfilled & 3 & 6 & 11 & 5 & 9 & 15 & 5 & 4 & 58 \\
\hline Standard indicator & 3 & 11 & 14 & 6 & 11 & 19 & 5 & 8 & 77 \\
\hline Not fulfilled & 0 & -5 & -3 & -1 & -3 & -4 & 0 & -4 & -20 \\
\hline Perecentage (\%) & 100 & 54 & 78 & 83 & 81 & 78 & 100 & 50 & 75.3 \\
\hline
\end{tabular}

Table 7

Source: Data Analysis Result (2018)

Mapping Data of Misykatul Anwar CLC

\begin{tabular}{|c|c|c|c|c|c|c|c|c|c|c|}
\hline \multirow{2}{*}{$\begin{array}{l}\text { Achievement } \\
\text { Targets }\end{array}$} & \multicolumn{8}{|c|}{ Standard } & \multirow{2}{*}{\multicolumn{2}{|c|}{ Total Description }} \\
\hline & 1 & 2 & 3 & 4 & 5 & 6 & 7 & 8 & & \\
\hline Fulfilled & 2 & 6 & 7 & 3 & 5 & 24 & 5 & 10 & 62 & \\
\hline Standard indicator & 2 & 8 & 7 & 6 & 6 & 28 & 5 & 10 & 72 & \\
\hline Not fulfilled & 0 & -2 & 0 & -3 & -1 & -4 & 0 & 0 & -10 & \\
\hline Percentage (\%) & 100 & 75 & 100 & 50 & 83 & 86 & 100 & 100 & 86.75 & \\
\hline
\end{tabular}

Source: Data Analysis Result (2018)

fulfilled 5 (11 indicators that must be fulfilled). From the standard process, this CTI obtained $78 \%$ with the number of indicators fulfilled 11 and not fulfilled 3 (14 indicators that must be fulfilled). From the standards of educators and education personnel, this CTI obtained $83 \%$ with the number of indicators fulfilled 5 and not fulfilled 1 ( 6 indicators that must be fulfilled). From facilities and infrastructure standards, this CTI obtained $81 \%$ with the number of indicators fulfilled 9 and not fulfilled 2 (11 indicators that must be fulfilled). From the management standard, this CTI obtained $78 \%$ with the number of indicators fulfilled 15 and not fulfilled 4 (19 indicators that must be fulfilled). From the financing standard, the CTI obtained $100 \%$ with the number of indicators fulfilled 5, which means this CTI fulfilled the 5 indicators that must be fulfilled. Last, in the assessment standard, the CTI obtained $50 \%$ with the number of indicators fulfilled 4 and not fulfilled 4 ( 8 indicators that must be fulfilled).

\section{The Quality Standards of CLC and CTI in Cimahi City}

Samples in Cimahi City are Misykatul Anwar CLC and An-Nur Harapan Ibu CTI, West Bandung Regency. Misykatul Anwar CLC is located at Tengah street No. 43 Cibabat, Cimahi City. Based on the eight National Education Standards, the results of mapping the quality standard indicators of Misykatul Anwar CLC are as in table 7.

Based on the results of data in table 7, the status of CLC Myskatul Anwar is very adequate with a percentage of $86.75 \%$. This is due to its success in fulfilling each of its standards. From the graduate competency standard, this CLC obtained $100 \%$ with the number of indicators fulfilled 2, which means this CLC has fulfilled 2 indicators that must be fulfilled. From the content standard, this CLC obtained $75 \%$ with the number of indicators fulfilled 6 and not fulfilled 2 ( 8 indicators that must be fulfilled). From the standard process, 
MIMBAR, Vol. 35 No. $2^{\text {nd }}(2019)$

Table 8

Mapping Data of Aditya Surya CTI

\begin{tabular}{|c|c|c|c|c|c|c|c|c|c|c|}
\hline \multirow{2}{*}{$\begin{array}{l}\text { Achievement } \\
\text { Targets }\end{array}$} & \multicolumn{8}{|c|}{ Standard } & \multirow[t]{2}{*}{ Total } & \multirow[t]{2}{*}{ Description } \\
\hline & 1 & 2 & 3 & 4 & 5 & 6 & 7 & 8 & & \\
\hline Fulfilled & 3 & 10 & 12 & 6 & 11 & 18 & 5 & 8 & 73 & \\
\hline Standard indicator & 3 & 11 & 14 & 6 & 11 & 19 & 5 & 8 & 77 & \\
\hline Not fulfilled & 0 & -1 & -2 & 0 & 0 & -1 & 0 & 0 & -4 & \\
\hline Percentage (\%) & 100 & 90 & 85 & 100 & 100 & 94 & 100 & 100 & 94.8 & \\
\hline
\end{tabular}

Source: Data Analysis Result (2018)

this CLC obtained $100 \%$ with the number of indicators fulfilled 7 , which means that this CLC has fulfilled 7 indicators that must be fulfilled. From the standards of educators and education personnel, this CLC obtained $50 \%$ with the number of indicators fulfilled 3 and not fulfilled 3 ( 6 indicators that must be fulfilled). From the standard of facilities and infrastructure, this CLC obtained $83 \%$ with the number of indicators fulfilled 5 and not fulfilled 1 ( 6 indicators that must be fulfilled). From the management standard, this CLC obtained $86 \%$ with the number of indicators fulfilled 24 and not fulfilled 4 (28 indicators that must be fulfilled). From the financing standard, this CLC obtained $100 \%$ with a number of indicators fulfilled 5 , which means that this CLC has fulfilled 5 indicators that must be fulfilled. Last, in the assessment standard, this CLC obtained $100 \%$ with the number of indicators fulfilled 10 , which means that this CLC has fulfilled the 10 indicators that must be fulfilled.

The results of mapping the eight National Education Standards of Aditya Surya CTI located at Leuwigoong street No. 93 RT 01/06, Karang Mekar, Central Cimahi Regency, Cimahi City are shown in table 8.

Based on the results of data in table 8 , the achievement status of CTI Aditya Surya is very adequate with a percentage of $94.8 \%$. This is due to its success in fulfilling each of its standards. From the competency standards, this CTI obtained $100 \%$ with the amount of indicators 3, which means that this CTI has fulfilled the 3 indicators that must be fulfilled. From the content standards, this CTI obtained $90 \%$ with the number of indicators fulfilled 10 and not fulfilled 1 (11 indicators that must be fulfilled). From the standard process, this CTI obtained $85 \%$ with the number of indicators fulfilled 12 and not fulfilled 2 (14 indicators that must be fulfilled). From the standards of educators and education personnel, this CTI obtained $100 \%$ with the number of indicators fulfilled 6, which means that this CTI has fulfilled the 6 indicators that must be fulfilled. From terms of facilities and infrastructure standards, this CTI obtained $100 \%$ with the number of indicators fulfilled 11 , which means that the CTI has fulfilled the 11 indicators that must be fulfilled. From the management standard, this CTI obtained $94 \%$ with a total of indicators fulfilled 18 and not fulfilled 1 (19 indicators that must be fulfilled). From the financing standard, this CTI obtained $100 \%$ with the number of indicators fulfilled 5 , which means that this CTI has fulfilled the 5 indicators that must be fulfilled. Last, in the assessment standard, the CTI obtained $100 \%$ with the number of indicators fulfilled 8 , which means that this CTI has fulfilled the 8 indicators that must be fulfilled.

\section{Description of the Development Conceptual Model of CLC and CTI Managers Performance}

The description of the conceptual model of CLC and CTI in Bandung was conducted to explore two things: first, the expectations of managers and educators at CLC and CTI, and second, the component of developing the performance of CLC and CTI managers in Bandung.

\section{Description of Expectations of Managers and Educators}

The results of observations on research subjects of managers and educators. The observed indicator relates to the expectations of research subjects regarding the performance of CLC and CTI managers in Bandung relating to the background, foundation, objectives, components, procedures, and feasibility tests of quality CLC and CTI models. The six things mentioned above are described as follows: First, the background of the need for a design or conceptual model for the performance of CLC and CTI managers. Managers and 
educators consider the need to explain the reasons and framework for developing the performance of CLC and CTI management that is arranged in a comprehensive and systematic way. Second, the foundation of developing the performance of CLC and CTI managers is based on empirical, philosophical and juridical. Third, the general objective of organizing CLC and CTI should be intended to increase the human development index (HDI) through the provision of learning opportunities, especially for community members. Fourth, the components of the performance development of CLC and CTI managers. Exploration of research subject expectations is important because it will show their real needs. The results of the study above show that the development of CLC capacity needs to be conducted as it is line with Tohani's research (2010: 179) which states that CLC needs to adapt and anticipate changes and take opportunities for the sustainability of CLC. Furthermore, Nugraha (2009: 118) explains that the programs prepared must fulfill the needs of the community through a need analysis instead of only making a list of wants.

\section{Description of Model Component}

Based on the results of interviews with managers and educators, the obligatory components in guiding the performance of managers in CLC and CTI are teaching materials, managers, learning resources, learning methods and strategies, learning media, learning tools, and education costs. Fifth, the procedures for implementing the development of manager's performance at CLC and CTI. The results of interviews with managers and elements of education office showed that the implementation of development of manager's performance at CLC and CTI should be carried out through the following steps: (1) planning is carried out by the education or finance department. The planned aspects are the arrangement of administrative services, minimum service standards, teaching staff, students, facilities, funding, and partnership nets according to the needs and potential of the community. The planning step begins with discussion of the preparation of the plan, the socialization of the plan, and the scheduling of activities. (2) the organizing is carried out by means of: first, arrange the organizational structure; second, set a job description; third, appoint the right people according to their expertise to occupy positions in the organizational structure. (3) the program implementation is directed to develop and implement work plans, learning facilities at CLC and CTI units is more to a mentoring service and learning independence for the community in the form of learning facilitation.

According to Hikmat(2001: 23), facilitation from outside the community and community involvement are oriented to strengthen the ability of the community to play an active role, (4) developing is carried out to improve the quality of process and the quality of good learning outcomes, (5) program evaluation conducted to assess the results of the performance of CLC and CTI managers. Evaluation approaches implemented are individual and group. The facilitation provided by CLC managers is in the form of empowerment-based guidance. As explained by Wahidah and Evita (2019: 15), that developing is how individuals, groups or communities try to control their own lives and try to shape the future according to their wishes.

\section{Conclusions}

The results of the study are as follows: first, the description of the management of CLC and CTI institutions in Bandung is still not optimal and does not reflect a systematic and continuous planning, implementation and evaluation process, so that it is necessary to analyze the causes of these weaknesses in each indicator of the institution's management standards. Second, the map of the quality standard indicators of CLC and CTI management units in Bandung has not yet achieved the targets as required in the eight National Education Standard indicators. Based on the results of the mapping, the quality of CLC and CTI reaches an average of $83 \%$, thus, it still needs further structuring which begins with an exploration of the expectations of managers to improve the quality of their institutions. Third, the expectations have been collected from CLC and CTI managers and educators about the need for an ideal model of performance management of CLC and CTI managers regarded the background, foundation, objectives, components, service procedures formulated as a development conceptual model of the managers' performance at CLC and CTI institutions in Bandung.

Suggestions for managers as follows: 
(1) improving the quality of institutional management, (2) utilizing the potential of the environment around CLC to improve the quality of learning services, and (3) increasing the number of partnerships with related institutions to improve curriculum and develop CSR funds. Suggestions for the District and City Education Offices are the need for intensified developing, especially in monitoring and handling obstacles faced by CLC and CTI managers, and encouraging CLC units to apply for institutional accreditation.

\section{References}

Abdulah, M.N.A., and Putra, R.R.S. (2018). Nyangku :Implementasi Nilai-Nilai Sosial Melalui Ritual Upacara Adat Desa Panjalu Ciamis Jawa Barat. Sosio Edukasi. Jurnal Studi Masyarakat dan Pendidikan. Universitas Hamzan wadi. Vol 2, No 1 Tahun 2018.

Amin, Y. (2014). Analisis Kebutuhan Pendidikan Masyarakat. Jurnal Penelitian Pendidikan. UNNES.Vol 31, No. 2 Tahun 2014.

Anwas. O. (2011). Strategi Pemanfaatan Media Pembelajaran dalam Meningkatkan Kompetensi Penyuluh Pertanian. Jurnal Teknodik. Jakarta: Pustekom Kemdikbud, Vol. XV No. 2, Desember 2011. ISSN 0854-915X, akeditasi LIPI No. 351/AkredLIPI/P2MBI/07/2011.

Ardiwinata, J.S. (2014). Peran Forum PKBM dalam Meningkatkan Mutu Pengelolaan Program PAUDNI di Provinsi Jawa Tengah dan DIY. Jurnal Pedagogia. Bandung: Fakultas IImu Pendidikan Universitas Pendidikan Indonesia, Vol. 1 No. 2, Desember 2014.

Arikunto, S. (2010). Prosedur Penelitian Suatu Pendekatan Praktik. Jakarta: RinekaCipta.

BSNP, No. 19 Tahun 2005 tentang Standar Nasional Pendidikan.

Firdausi, K.S. (2016). Analisis Pembangunan Berbasis Masyarakat dalam Pengembangan Sumber Daya Masyarakat. JISIP: Jurnal Ilmu Sosial Dan Ilmu Politik. FISIP, Universitas Tribuhwanatunggadewi Malang. ISSN. 2442-6962, Vol. 5, No. 2. Tahun 2016.

Hikmat, H., (2001). Strategi Pemberdayaan Masyarakat. Bandung: Humaniora Utama.

Hayati, L. (2011). Penerapan Pendekatan Pemecahan Masalah Melalui Belajar dalam Kelompok Kecil Untuk Meningkatkan Prestasi Belajar pada Mata Kuliah Teori Peluang. Jurnal Teknodik Pustekom Kemdikbud Vol. XVI. No. 2 Juni 2012.
ISSN 0854-915X, akeditasi LIPI No. 351/ Akred-LIPI/P2MBI/07/2011.

Hermawan, Y. dan Suryono. (2016) Partisipasi Masyarakat Dalam Penyelenggaraan Program-Program Pusat Kegiatan Belajar Masyarakat Ngudi Kapinteran. Jurnal Pendidikan Dan Pemberdayaan Masyarakat. Vol 3, No 1 (2016. March 2016. Prodi Pls Pascasarajana UNY.

Helmut, W. (1991). Peningkatan Pendidikan Masyarakat Minahasa Dan Dampaknya: Tinjauan Ekonomi Dan Sosial. Populasi: Jurnal Pendidikan Dan Kebijakan UGM. Vol. 2 No. 2 Tahun 1991.

Iskandar, D. (2017). Pemberdayaan Masyarakat Dalam Bidang Pertanian oleh Lembaga Pemberdayaan Masyarakat Di Desa Jadimulya Kecamatan Langkaplancer Kabupaten Pangandaran. Moderat: Jurnal Ilmiah Ilmu Pemerintahan. UNIGAL.Vol. 3, No 1. Tahun 2017.

Jalal F., dan Supriadi, D. (2001) Pengembangan CBE dalam Lapangan Pendidikan. Jakarta: Depdiknas.

Nugraha, A. (2009). Pengembangan Masyarakat Pembangunan Melalui Pendampingan Sosial Dalam Konsep Pemberdayaan Di Bidang Ekonomi. Jurnal Ekonomi Modernisasi Fakultas Ekonomi Universitas Kanjuruhan Malang. Vol. 5 No. 2 Juni 2009.

Septrilia, Husin, Hakim. (2019).Pemberdayaan Perempuan Melalui Pelatihan Keterampilan Tudung Saji Dari Rotan Di Desa Muara Tenang Kecamatan Dempo Selatan Kota Pagar Alam. Jurnal Pendidikan Dan Pemberdayaan Masyarakat. Program Studi Pendidikan Luar Sekolah Jurusan Ilmu Pendidikan FKIP UNSRI. Vol 6. No. 1 Tahun 2019.

Saepudin, A. (2015). Efektifitas Pelatihan dan Efikasi Diri dalam Meningkatkan Perilaku Berwirausaha pada Masyarakat Transisi. Jurnal Mimbar (Sosial dan Pembangunan). Bandung: P2U LPPM UNISBA, Vol. 31 No. 1. Juni 2015. ISSN: 0215-8175, Terakreditasi Dikti. SK Kemdikbud No. 040/P/2014.

Saepudin, A. (2017). The Influence of Participation in Extracurricular Activities to Learning Motivation. P2U LPPM UNISBA, Vol. 33 No. 2. Desember2017. ISSN: 0215-8175, Terakreditasi Dikti. SK Kemdikbud No. 040/P/2014.

Sugiyono. (2012). Metode Penelitian Kombinasi (Mixed Method). Bandung: Alfabeta.

Sihombing dan Gutama (2000). PKBM dalam Perspektif Pendidikan Luar Sekolah. 
Jakarta: Depdiknas.

Sihombing. (2019). Pendidikan Luar Sekolah. Jakarta: Depdiknas.

Suharto, T. (2005). Konsep Dasar Pendidikan Berbasis Masyarakat. Jurnal Cakrawala Pendidikan, Vol. 2, No. 3, November 2005.

Tohani, E. (2010). Studi Pengembangan Kapasistas PKBM sebagai Penyedia Layanan Bidang Pendidikan. Jurnal Penelitian Illmu Pendidikan Vol. 3 No.2, September 2010.

UUSPN (Undang-Undang Sistem Pendidikan Nasional) No. 20 Tahun 2003 tentang Sistem Pendidikan Nasional.

Widodo, WE. (2019). MengukurKepuasan
Masyarakat Pada Program CSR Di DesaKertajaya: Sebuah Analisis Menggunakan Metode Sustainability Compass. Jurnal Pemberdayan Masyarakat: Media Pemikiran Dan Dakwah Pembangunan. UIN Sunankalijaga. Vol 3. No. 1 tahun 2019.

Wahidah, and Evita. (2019). Pembinaan Masyarakat Pada Perempuan Tulang Punggung Keluarga Dengan Strategi Koping Mekanisme Dalam Upaya Peningkatan Resiliensi. Community Development: Jurnal Pengembangan Masyarakat Islam, STAIN Kudus. Vol. 3. No. 1, Juni 2019. 